\title{
Management Of Teaching Practice In The Preparation Of Nigerian Certificate Of Education (NCE) Teachers
}

Samuel Adetunji Asaya, Crawford University, Nigeria

\begin{abstract}
If the teacher must be "everything" to the learner as well as be the character-model to society, as it is commonly expected, his training must be such that is not only comprehensive but well articulated. Such training must be based on sound conceptual understanding and reasoning that have been developed within the matrix of practice and experience (Ehiametalor, 1990).

Consequently, this paper examines a brief historical background of the teacher training institutions in Nigeria, taking a look at the meaning and objectives of teaching practice and some management problems militating against the professional preparation of teachers-in-training. This paper further considers the strategies that could improve the management and supervision of teaching practice, generally, and in colleges of education, in particular. Suggestions are made on how to ensure that the professionally prepared teachers are retained in the education system through appropriate incentives and motivation.
\end{abstract}

Keywords: Historical background of Teacher Training Institutions in Nigeria, Management of Teaching Practice Exercise, Professional preparation of Nigeria Certificate of Education teachers in Nigeria

\section{INTRODUCTION}

hen the first institution for the training of what we would call today 'middle level' teachers was
established in the early 60's in Nigeria, the college, which was later changed to Advanced Teacher
Training College, was meant to produce teachers for the secondary school system of the country. These teachers were trained leading to the award of the National Certificate of Education (Baikie, 2002). The National Policy on Education (1981), as a matter of policy, regarded the NCE as the minimum qualification for entry into the teaching profession. This, in effect, means that primary schools will be staffed by holders of the National Certificate of Education (NCE). The decision to make NCE as the minimum qualification for entry into the teaching profession calls for a total overhaul of the NCE programmes.

The orientation and training of teachers must now conform not only with aims and objectives of the primary school system, but also with educational objectives of the nation.

Rao (2007) declared that teachers are also the most expensive inputs of the system, even when they claim to be grossly underpaid. The improvement of pursuit and attainment of worthwhile education, aims, and objectives can only be realized when we have a caliber of professional teachers who have good educational backgrounds and relevant teaching skills and attitudes. Our educational institutions must provide education that offers opportunities of self-fulfillment for our students. Only teachers who possess the necessary technical competence and professional skills through a well-coordinated teacher education programme can rise to meet the challenges of the crisis that has bedeviled Nigeria's educational scene. The original aim of teacher education programmes was the training of apprentice teachers. This was to be achieved by observing and imitating more experienced teachers on the job. Teaching practice was conceived as the practical mastery of the art of teaching by actual participation in classroom teaching under the critical eyes of an expert and experienced teacher as supervisor and tutor. Historically, therefore, 
teaching practice was structured to involve cooperating agents and agencies. In the present day arrangement, these include universities, ministries education, principals, teachers, and students of secondary schools and teacher training colleges, parents and community members.

\section{CONCEPT OF TEACHING PRACTICE}

Teaching practice is an essential component of teacher preparation. It gives teacher trainees the opportunity to experience life in the classroom first-hand and to put into practice the theories of teaching learned during contact sessions and classroom observation. The chance to interact with experienced teachers in schools provides a golden opportunity to beginning teachers. Even those who have been through some initial training have much to learn by observing other teachers teaching in an entirely different school (NTI, 2003).

Teaching practice is also seen as providing the time, as well as the avenues, for the teacher-in-training to acquire necessary experience, knowledge, attitude, skills, and competencies that are imperative to his total education. Correspondingly, it allows the student-teacher the opportunity to try out, in actual classroom situations, what he has already acquired in terms of concepts, principles, theories of teaching, and learning. The challenges posed by the exercise enable the trainee to audit himself, his emotions, and capabilities, thereby equipping himself adequately for making the decision to choose between staying in teaching or quitting the "profession".

Afe (1990) states, "it is a practical exercise that every student-teacher must undergo to be able to adjust and to have met the requirements for the award of a certificate or degree in education. According to him, the exercise is to the teacher-in-training what internship is to medical doctors or an apprenticeship is to technicians. Afe, 1990 (citing Gohen and Garner, 1979) described teaching practice "as the period for the student-teacher to put into application some of the psychology methods and principles he has learned theoretically in lecture rooms".

According to Ogunbameru (2004), available literature shows that there is a wide range of views with regard to the usefulness of teaching practice in teacher education programmes. While Balogun (1974) believes that supervision can affect the quality of teaching, Bowan (1979) and Fagbulu (1984) question the present value and quality of supervision and, in return, have suggested more techniques. Akimoyewa (1990) defined the term "teaching" in an apprenticeship system and a Teacher Education Programme is not complete without the exercise".

Practice teaching, as it is commonly called, is the opportunity for the student-teacher to put into practice all the knowledge and theories in child and adolescent psychology, learning theories, guidance and counseling, classroom management, educational administration, planning and supervision, curriculum development, test, measurement and evaluation, instructional technology, micro-teaching, etc.

Haines (1960) defines teaching practice as a period of pre-teaching, supervised as part of the experience in a College programme. It can also be seen as an apprenticeship or a period of internship, which constitutes the gateway to one of the world's greatest professions (Martin and Wescott, 1963). Teaching practice allows a demonstration of skills; permits the trainee-teacher to learn experience, as well as from a specialist opinion. It is a core course in all teacher education programmes.

In the words of Kreitner and Kinicki (2004), the period of teaching practice gives an opportunity to studentteachers to gain practical classroom experience under a supervisor. It exposes the trainee to classroom criticisms, vigilance, team spirit and integration of oneself unto a school environment. It is equally a period of experimentation since most students, at this time, apply new ideas, new techniques, strategies, and methodologies in actual classroom situations after having learned so much theoretically.

All the aforementioned authors emphasize the fact that every teacher education programme includes all experiences that the students are preparing for active work with pupils and encounter or experience during a period of special assignment at school. 


\section{OBJECTIVES OF TEACHING PRACTICE}

Nakpodia, E. D. (2001), is of the opinion that teaching practice is not only an important and vital aspect, but also an indispensable area for the teacher in the teacher education programme. It enables the student-teacher not only to relate theory to practice of education, but equips him to meet the challenges of these professional demands. Based on the works of Cope (1971), Flanders (1970) and Afe (1990), considering teaching effectiveness as the ultimate objectives of teaching practice, suggested the following objectives. They should enable student-teachers to:

1. Apply the principles of the professional's sources taken to the teaching learning classroom process that will bring meaningful changes in learning

2. Develop the skills and competencies of teaching

3. Organize the scheme of work and lesson notes content around major concepts and generalizations that may facilitate sequential learning

4. Become familiar with a variety of teaching strategies and instructional resources that are appropriate to achieve overall teaching-learning objectives

5. Study and diagnose the scholastic difficulties of pupils that may arise from behavioural problems and provide guidance and remedial instruction to those who need it

6. Apply the principles of evaluation in assessing the effectiveness of their teaching, as well as the progress of their pupils, as a means of improving instruction

7. Acquire skills in democratic classroom management and conduct of pupils activities

8. Participate actively and effectively in the various instructional and non-instructional programmes and activities of the school in which they will be serving

9. Establish good human relations with individual, small or large groups, with staff, parents and other members of the community

10. Provide the opportunity to participate in community activities that will enhance the professional growth of a teacher

Since a major assumption on which teaching practice is based is to enable the teacher to become effective, purposeful, successful, and meaningful in his professions, Cope (1971) further highlighted the following objectives:

1. Provision of opportunities to put theory into practice

2. Gives practical experience opportunity and facilities for self-confidence and expertise

3. Provision of ability to organize control manage classroom with due disciplinary measures

4. To develop an integration and mutual sense of cooperation, as well as interchange of ideas and attitudes

These lofty objectives neatly expressed the obvious facts that their attainment guarantees successful teaching and spells out expertise training in knowledge, skills of participatory organization, leadership, and management of human resources for valuable learning effectiveness in the classroom situation.

Mullins L. J. (2002) said, it now becomes obvious that teaching practice demands possession of certain qualities in order to be effective. Such qualities range from knowing his stuff, being interested in the subject, and knowing and loving his pupils.

\section{PROBLEMS}

Imogie (1990) expressed, with dismay, the disturbing situation existing due to financial and human resource constraints in most colleges of education, thereby beginning to make a mockery of the exercise in several ways. These include shortening of the duration of the exercise by the appropriate authorities and or by equating micro-teaching with field teaching practice. The result is that most student-teachers do not take the exercise seriously as they hardly appreciate the relevance and contribution of it to their professional training and calling.

A lot of comments have recently been made about the desirability, or otherwise of teaching practice, in teacher education programmes. The public schools, characterized by an unpredictable school calendar, inexperienced teacher educators, lukewarm attitude of school heads, teachers, lack of instructional resources in the 
school and, more importantly, very harsh economic situations, led to the haphazard nature of the teaching practice organization, structure and implementation.

Sunita (2000) opined, "It seems reasonable to suppose that some teachers will continue to leave the profession in preference for other vocations as long as their (the teachers) preparation lacks distinctiveness and thoroughness in addition to other factors. A disconcerting number of teachers will continue to drop out after a brief experience as long as the profession has no share in determining the nature of the training and induction of those who become its members."

Above all, as long as the profession makes no provision for the recognition of merit and exceptional performance and no provision for differentiation of functions within the job of teaching itself, there will continue to be an uninterrupted outpouring of experienced teachers from the teaching field to seek better remunerative jobs elsewhere.

\section{STRATEGIES FOR EFFECTIVE MANAGEMENT AND SUPERVISION}

The student-teachers' sojourns in his or her host school during teaching practice are comparatively short. Consequently, it is important that his or her stay should be closely monitored and effectively supervised within available time and resources. The suggestions enumerated hereunder should assist the supervisor in the management of the student-teacher.

\section{When to Visit Student Teachers}

Deriving from relevant literature and personal experience, the first visit should come in the first week of the teaching practice period. This visit is usually not the time to begin the evaluation of student-teachers, but a time to help them settle down. It is a time to listen to their problems and advise and assist them accordingly. The internal supervisor should use this opportunity to discuss, with the principal of the cooperating school, the roles expected of him and the assistance that could be rendered to the student. This visit helps to prepare the students physically and psychologically for actual teaching. Evaluation could then begin in subsequent visits that should come up no later than two weeks after the first visit.

\section{Time Spent with Students}

Most supervisors, whether internal or external, often appear to be running against time. They want to see as many students as possible within a limited time. Eventually the supervisor ends up spending only 10 to 20 minutes with a student-teacher (Money, 1990). At times he may not have the time to discuss his findings with the student.

To adequately supervise the teaching of a student, emphasis should not be on how far, but how well the supervision is done. In view of this, a reasonable length of time should be spent with the student during teaching to be able to follow every facet of the lesson for the purpose of giving adequate guidance. It is suggested that a supervisor should stay with the student for the entire period of the lesson or at least for 30 minutes from the beginning, with an additional 10 to 15 minutes to discuss, with the student, his strengths and weaknesses.

\section{Number of Times a Supervisor should see a Student}

The issue of systematically monitoring the progress of a student-teacher's teaching proficiency is of concern to every institution organizing teaching practice. One of the ways of accommodating this concern is to have one supervisor visit a student at least twice consecutively. It is important that the supervisor takes his comments from the first visit along to the second visit. This will enable him to compare his comments from the first visit and identify areas of improvement. This will place the supervisor in a better position to evaluate and advise the studentteacher effectively. 


\section{Having Students Supervised by more than One Supervisor}

It is important to look into ways of enhancing the objectivity of evaluation of students on teaching practice. One way of ensuring this is to have two or more supervisors see the same student, either having the supervisors see the same student at the same time or rotating them in the schedule of supervision.

\section{Frequency of Supervision}

There is no hard and fast rule as to the total number of times a student should be seen during the entire period of teaching practice. It is, however, suggested that a student be supervised as many times as possible. The question is the interpretation of "many times". Some authors have suggested at least two times (Olaitan and Agusiobo, 1981). In this paper, it is suggested that each student on teaching practice should be supervised at least three times. This will enable the institutions, particularly colleges of education where the teaching practice grade appears on students' certificates, to get the true or objective performance of the student-teacher. These certificates are going to be carried for life and they bear the name of the institution, so a lot of care is necessary to be sure that whatever grades are on them are true reflections of the student's ability.

\section{Regularity of Visits}

There is the tendency for students to relax their effort s once a supervisor has come and gone once or twice. This may be a sequel to the assumption that the supervisor may not come again or it will take some time for him to come back. In view of this, the supervisors' visits should be staggered to ensure regularity. Regular visits will make the presence of the college or institution constantly felt in the cooperating schools, which will, in turn, encourage the schools and the student-teachers to work conscientiously.

\section{CONCLUSION}

\section{Prospects}

Ehiametalor (1990) expressed the view that if the teacher must be "everything" to the learner, as well as be the character model to the society, as it is commonly expected, his training must be such that is not only comprehensive, but well articulated. profession if:

We can, in the light of our discussion, summarize that teachers, in general, will stay in the teaching

1. They are satisfied with the conditions under which they work,

2. They are satisfied with the living conditions in the community where they work,

3. The profession is self-respecting and has control over its own affairs,

4. There are opportunities for advancement in their work,

5. Financial incentives, in the form of residential quarters, extended educational opportunities and other incentives, are added to normal salaries, and

6. They are adequately trained for the job they are expected to do.

Peretomode and Peretomode (2002) further stressed the fact that there will always be movement of teachers from the profession. This is to be expected in any profession, but the retention of teachers may be increased if the above conditions are satisfied. The level of training of the teacher, the degree of support he gets from the community, the extent to which he controls his own working situation, and the prestige which his profession has earned in the community are all factors which can influence his retention in the profession.

\section{Responsibility as Teacher Educators}

In conclusion, as teachers, we have a responsibility, as educators, to ensure that student-teachers are properly guided into developing the appropriate professional wherewithal that would turn them into good and 
effective teachers. We can do this in a number of ways:

1. By ensuring that the students are properly motivated to teaching

2. $\quad$ By guiding students toward new knowledge, behaviour and expected capabilities

3. By providing extensive and meaningful materials and experience for students

4. Organizing learning experiences so that their sequential and correlative aspect is apparent to the students

5. Assisting students in defining acceptable standards of performance and providing them with means for judging performance in relation to those students

Consequently, an assessment of any teaching practice component of teacher education programmes must be based on its ability to provide useful, relevant, practical orientation for student-teachers who, upon graduation, will be experienced, confident, perceptive, and effective in the performance of their total roles as professional teachers.

\section{AUTHOR INFORMATION}

Samuel Adetunji Asaya is a Chief Lecturer in Educational Management of College of Education, Ekiadolor-Benin. Edo State of Nigeria. He is currently on Sabbatical Leave as lecturer in the Department of Industrial Relations and Personnel Management at Crawford University, Igbesa, Ogun State, Nigeria.

\section{REFERENCES}

1. Afe. J. O (1990) A system approach to the organization supervision and evaluation of teaching practice in Faculty of Education (Ed) University of Benin Faculty of Education Seminar Series - Teaching Practice Benin - City.

2. Baike, A. (2002) Recurrent Issues in Nigerian Education, Zaria, Tamaza, Publishing Co.

3. Bakie A., (2002) Retention of teachers and their conditions of service in Recurrent Issues in Nigeria Education, Zaria, Tamaza Publishing Co. Ltd. 32.

4. Balogun I. A. (1984) "Specialist versus non-specialist supervision of student teachers" in The Organization Supervision and Evaluation of Teaching Practice (Ed) O. M. Onibokun Ibadan Evans Brothers (Nig) Publishers Ltd.

5. Bowan, N. (1979) "College supervision of student teaching: a time to reconsider" Journal of Teacher Education Vol XXX No. 3, May/June.

6. Cope, E. (1971) "School of Experience in Teacher Examination" Education Research, 12 87-89.

7. Ehiametalor, E. T. (1990) Forward in First Faculty of Education Seminar Series University of Benin, Benin City, Nigeria.

8. Fagbulu, A. M. (1984) "Towards appropriate organizational models for teaching practice in The Organization Supervision and Evaluation of Teaching Practice (Ed) O. M Onibokun, Ibadan: Evans Brothers (Nig) Publishers Ltd.

9. $\quad$ Falayaje W. (1976) "The use of cooperating teachers in Teaching Practice of Supervising Prospective Graduate Teachers the Professional Way". Ibadan: Evans Brothers (Nig) Publishers Ltd.

10. Flanders, N. (1970) Analyzing Teaching Behaviour. London Addison - Wesley, Reading Mass and London.

11. Imogie, 1. (1990) Student practice teaching and the professional training of teacher in Nigeria: the need for a new strategy for the $21^{\text {st }}$ century, University of Benin, Faculty of Education Seminar Series - Teaching Practice, Benin - City.

12. Meture, S. O (1984) "Supervising mature trainee teachers spread across a wide geographical area" in O. M. Onibokun (Ed) The Organization, Supervision And Evaluation of Teaching Practice, Ibadan: Evans Brothers (Nig) Publishers Ltd.

13. Money, F. O. (1990) Towards a more effective supervision and evaluation of student teachers during teaching practice in First Faculty of Education Seminar Series, University of Benin, Benin City, Nigeria.

14. Mullins L. J. (2002) Management and Organizational Behaviour, Harlow, Pearson Education Ltd. 693 700 .

15. Nayak, A. K. and Rao, V. K. (2004) Classroom Teaching Methods and Practices, A. P. H. Publishing Corporation, $196-198$. 
16. Nakpodia, E. D., (2001) The role of educational administrators in the promotion of in-service teacher education for primary school teachers in nigeria in Nwagwu, N. A., Ehiametalor, E. T., Ogunu, M. A., Nwadiani (ed) (2001) Current Issues in Educational Management in Nigeria, Benin City, NAEAP. 379 382.

17. Ogunbameru, O. A. (2004) Organizational Dynamics, Abuja, Spectrum Books Ltd, (257).

18. Odor, C. O. (2003) A Short History of Western Education, Nsukka, Chuka Educational Publishers.

19. Olaitan, S. O and Agusiobo O. N (1981), Principles of Teaching Practice Ibadan Spectrum Books Limited.

20. Peretomode V. F. Peretomode O., (2002) Human Resources Management, Lagos, O. O. Publishers Ltd. $(101-102)$.

21. Singh, Y. K and Sharma A., (2004) Micro Teaching, New Delli A.P.H. Publishing Corporation, 27-28, 33 34.

22. Rao, V. K (2007) Higher Education, New Delli, A. P. H. Publishing Corporation 41 -42. 


\section{NOTES}

